\title{
25 EDITORIAL
}

El 30 de octubre del año pasado, Estudios Sociales sufrió otra pérdida irreparable, con la desaparición física de Eduardo Hourcade, miembro fundador y de su consejo editorial. Las palabras que el director de la revista, Hugo Quiroga, y el historiador Fernando Devoto, miembro del Consejo Asesor, escribieran constituyen una evocación insuperable de su figura. Reproducimos los textos a continuación, en memoria de nuestro amigo y colega ${ }^{1}$.

\section{UN HISTORIADOR DE TALENTO}

Hablar de Eduardo es hablar de un ami- ramentos, opiniones y pasiones diferentes go entrañable, muy querido, y de una fi- a las suyas. Pensaba por sí mismo. Fue un gura intelectual reconocida y prestigiosa. historiador de talento, formado básicaLo conocí en 1984 a mi regreso del exilio, mente en Francia, en donde hizo su docme lo presentó Ricardo Falcón. De ahí en torado, y mantenía vínculos académicos más entablamos una profunda amistad permanentes con las principales figuras de que el tiempo consolidó. Eduardo era due- ese país, en los temas de su especialidad. ño de una conversación amena, afectuosa, En esa reluciente trayectoria participó de pero siempre aguda, con razonamientos un emprendimiento académico de gran filo-sos. Argumentaba y contraargumen- relevancia en el mundo científico, la creataba con capacidad asombrosa, siempre ción de la revista Estudios Sociales en 1991, abierto y receptivo, sin temor ante tempe- de la Universidad Nacional del Litoral.

\footnotetext{
${ }^{1}$ Ambos textos fueron publicados en el suplemento «Más» del diario La Capital, el 21 de febrero de 2016. Agradecemos la generosidad de Fernando Devoto.
} 
Fue uno de sus fundadores y miembro del consejo editorial hasta el final. En los inicios de una revista universitaria del interior fue un verdadero militante, la hacía circular personalmente en Buenos Aires entre instituciones y profesores universitarios. En esta evocación no puedo dejar de mencionar su rol de profesor. Eduardo amaba la enseñanza, jerarquizaba esa función como pocos, la cumplía con un copioso compromiso, atrapaba al público por su erudición y por la coherencia en la línea argumental. Sus seminarios fueron célebres, podía hablar tres horas sin ningún papel en la mano sin perder el hilo conductor de su disertación. Sus alumnos lo recuerdan como el mejor de sus profesores. Se nos fue muy temprano.

\section{Hugo Quiroga}

\section{ENTRE EL PASADO Y EL PRESENTE}

Con la partida de Eduardo Hourcade se fue un amigo, un historiador y un testimonio de un tiempo que fue. De los años 70 en los que se formó conservó una idea, la no ociosidad de la historia, y algunas lecturas que perduraron en él, de Eric Hobsbawm (que poblaba la bibliografía de sus cursos de Historia Social Contemporánea) a Marc Bloch, al que dedicó un libro (junto a Cristina Godoy) en el que además de una introducción traducía al castellano algunos de sus ensayos seminales. El título que le dio sugiere aquella idea de la historia que fue suya: "Marc Bloch: una historia viva». Le interesaba el pasado porque le interesaba el presente. Empero, le interesaba también el pasado por el pasado mismo, como mostraban su amistad con libreros y editores, su bibliofilia o su coleccionismo de cosas pretéritas (como las radios a transistores). "Curiosidad por el mundo", la célebre fórmula de Jacob Burckhardt, era también la suya, y esa curiosidad casi ilimitada lo llevaba a cambiar de registros y de temas con frecuencia inusual. De ese modo, por ejemplo, pudo escribir en 1993 una tesis de maestría sobre «Ricardo Rojas: un pasado para la democracia argentina" y 10 años después una tesis de doctorado en la célebre École des Hautes Études en Sciences Sociales de París (bajo la dirección de Roger Chartier) sobre un argumento y un periodo muy diferente: «La construction culturelle d'une société nouvelle: le Rio de la Plata et ses rapports avec la France et l'Europe 1800-1850", textos ambos de los que publicaría sólo fragmentos y que pensaba finalmente editar en Argentina y en Francia este año. La sorpresiva muerte se interpuso. La muerte, tema sobre el que le gustaba reflexionar 
con ironía y escepticismo y sobre la que escribió ensayos penetrantes, desde luego porque conocía como pocos la nueva historiografía internacional que se abría camino en los ochenta, entre la historia social y la cultural, pero también porque le era un argumento muy congenial. He ahí, por ejemplo, el brillante texto que escribiría sobre la de Lisandro de la Torre, «La muerte del tribuno", en un volumen también cocompilado por él sobre La muerte en la cultura. De ahí quizás también su curioso interés por Chateaubriand, en el que se detuvo largamente en esa tesis de doctorado centrada en la circulación de libros e ideas entre Francia y lo que llamamos Argentina. Con todo, en el conjunto de una producción muy variada y a veces recóndita, un eje puede detectarse: su interés por la historiografía, por la memoria pública y el patrimonio. Es decir, más que los «hechos» le interesaban las construcciones (o fabricaciones o representaciones) que los historiadores o las elites hacían sobre el pasado. A esas operaciones aplicaba su aguda inteligencia y una mirada desacralizadora que reposaba en su amable y perspicaz interés por las fabulaciones humanas. Véanse, a modo de ejemplo, el magnífico ensayo que dedicó a "los usos del Monumento a la Bandera» o aquel otro sobre «Ricardo Rojas, hagiógrafo». Sus dos mundos fueron Rosario y París. Buenos Aires era apenas un lugar de tránsito, iba, hacía lo requerido y vol- vía prontamente a Retiro para retornar a esa ciudad que era tan suya. París, por su parte, era un lugar donde había estado tantas veces, primero como becario y luego como profesor. Allí estuvo por última vez el año pasado y pudo permanecer tres meses gracias a una invitación de la École y allí esperaba volver por otros tres en el 2016, con invitación o sin ella, según me dijo. París era para él tantas cosas: las bibliotecas y las librerías, las calles que le gustaba caminar pero también el lugar donde se encontraba con sus colegas e interlocutores preferidos, de Chartier a François Hartog, de Jacques Revel a Patrice Vermeren. Pero París era también el lugar con el que habían interactuado fuertemente otros historiadores que no eran franceses pero a los que también cultivaba, personal o intelectualmente, desde Robert Darnton (al que dedicó un fino y equilibrado ensayo en torno a los debates que surcaban su obra) a Giovanni Levi. Emblemas casi todos de eso que iba a llamarse «nueva historia» que pugnaba por dejar atrás, no siempre con justicia, a los grandes antepasados pero también, y aquí sí pertinentemente, a los dogmatismos que habían poblado la estación historiográfica precedente y que en Argentina y en Rosario sobrevivían pugnaces. Le tocó convivir con éstos y lo hizo con humor y con esas buenas maneras de su don de gentes. No le interesaban mucho historiográficamente, como tampoco le intere- 
saban los academicismos, con toga o sin indexadas), en las que no creyó nunca. toga, ni las coteries. Sobre todo ello obser- La historia era para él una pasión, no una vó una vez con gracia, en torno al 2013, profesión; los temas que le interesaban, que una de las cosas más curiosas era que no los que deberían haberle interesado había podido sobrevivir por 30 años inin- según las mudables convenciones del terrumpidos en una universidad a la que gremio; los tiempos, los suyos. $\mathrm{Y}$ en este se había incorporado con el retorno de la sentido, él no sólo era un ejemplo por sus democracia que parecía aspirar a desatar trabajos de historiador o por su generosi(verbalmente) todas las tormentas del dad como profesor, sino que era un notamundo. Y todavía podría agregarse que ble testimonio de que había otra forma, lo hizo sin doblegarse tampoco a las ló- más original, más honesta, más auténtica gicas que suelen llamarse científicas, que de colocarse en el mundo intelectual. consisten en especialización exasperada, papers, congresos y artículos (en revistas Fernando Devoto 